\title{
PROSPECTS OF THE ENVIRONMENTAL TECHNOLOGIES IMPLEMENTATION IN THE CEMENT INDUSTRY IN RUSSIA
}

\author{
Galina Peshkova', Alexei Cherepovitsyn², Pavel Tcvetkov²
}

1 Saint-Petersburg State University of Aerospace Instrumentation, 67 Bolshaya Morskaia, 190000, Saint Petersburg, Russia

2 Saint-Petersburg Mining University, $21^{\text {st }}$ Line, Vasilevsky Island, Building 2, Saint Petersburg, 199106, Russia, e-mail: pscvetkov@yandex.ru

Received: 2016.05.19

Accepted: 2016.08.10

Published: 2016.09.20

\begin{abstract}
Russian cement industry is in decline. Enterprises operate on the basis of technologies developed in USSR. In this connection such fundamental issues of the enterprises functioning, as energy efficiency, environmental safety, resource-saving, resources provision and others, are overlooked. The paper attempts to define the priorities of the Russian cement industry development based on the experience of developed countries. The most promising technologies for the designated key areas were described and their benefits and drawbacks were identified. Due to the major role of the raw resources in Russian economy, the issues of increasing the efficiency of cement plants, should be discussed with considering the efficiency of mining enterprises extracting mineral raw materials needed for manufacturing process. Given the significant investments required to the industry modernization, which can not be achieved through government support, it is proposed to create conditions for the development of the integrated companies. In addition, a key factor that can ensure the sustainable development of the industry is a cross-sectoral co-operation, which will allow to organize a low-waste production cycle with a minimal costs of raw materials.
\end{abstract}

Keywords: cement industry, ecology, limestone, clay, Russia, cross-sectoral cooperation, environmental technologies

\section{INTRODUCTION}

Construction is one of the basic Russian industries, which plays a significant role in the economy (Table 1). Four key points can express its economic importance. Firstly, it provides a significant part of the country's population employment (more than 7\% [FSS 2016]). Secondly, the quality of life in the country depends on the volume of construction (increasing the housing area per 1 person). Thirdly, construction industry forms the basis for the development of service sector and industries providing resources. Fourthly, the implementation of large construction projects, such as apartment complexes, could attract new residents in the region. Development of construction industry is connected with the increasing in number of companies involved in the industry (Figure 1).

The increase in the number of companies leads to increasing the number of ongoing projects what, on the one hand, is a factor of improving the quality of life, but, on the other hand, is direct and indirect factor of increasing anthropogenic impact on the environment.

The direct impact of construction industry is connected with the number of projects. Despite a trend of environmentally friendly technologies implementation [Didenko and Skripnuk 2014], it is ordinary in Russia that the regulatory authorities requirements performed only on paper. Many examples of such a situation could be found in mass media. The indirect impact includes the need of increasing raw building materials produc- 
Table 1. Share of construction industry in GDP of the Russian Federation [FSS 2016]

\begin{tabular}{|c|c|c|c|}
\hline Year & Share, $\%$ & Year & Share, $\%$ \\
\hline 2002 & 4.74 & 2008 & 5.39 \\
\hline 2003 & 5.32 & 2009 & 5.42 \\
\hline 2004 & 4.97 & 2010 & 5.59 \\
\hline 2005 & 4.58 & 2011 & 7.04 \\
\hline 2006 & 4.47 & 2012 & 6.40 \\
\hline 2007 & 4.91 & 2013 & 6.08 \\
\hline
\end{tabular}

tion volume, what as seen on the example of cement (Figure 2).

From 2000 to 2014 the volume of cement production in Russia doubled, and according to [Vysockiy 2013], in 2020 cement production will grow up to 90 million tons per year (in 1.5 times compared to 2014). At the same time, about $75-80 \%$ of the Russian cement industry capacities need to be modernized [Kasyanov 2009]. It will require more than 6.5 billion euros.
The major part of Russian cement plants operate with using equipment of the Soviet period (Table 2), so they have nothing in common with modern environmental technologies. Cement industry produces about $5 \%$ of total $\mathrm{CO}_{2}$ emission, which could be used in other sectors of the economy due to implementation of the innovative $\mathrm{CO} 2$ capture technologies [Tcvetkov and Cherepovitsyn 2016] during the processes of fuel combustion and chemical reactions (about $83 \%$ of total $\mathrm{CO}_{2}$ emission) [ClimaTechWiki 2010].

Such technologies are relevant to Russia, especially in a view of signing the Paris agreement on climate change in April 2016. Despite some criticizing against this agreement, it is an important step for Russia taking "environmental obligations" to the global community.

The increase in cement production determines the necessity of clay and limestone mining enlargement (the key components for its production in Russia). According to Russian government regulation, clay and limestone are common min-

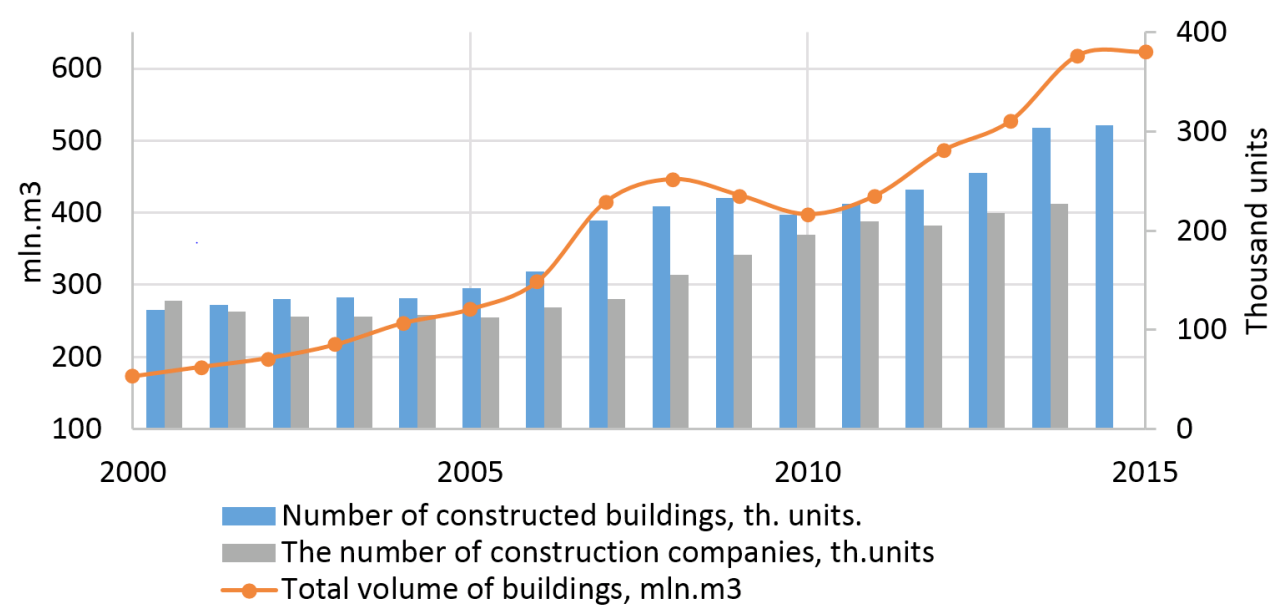

Figure 1. Relation between total volume of constructed buildings and number of construction companies in Russia

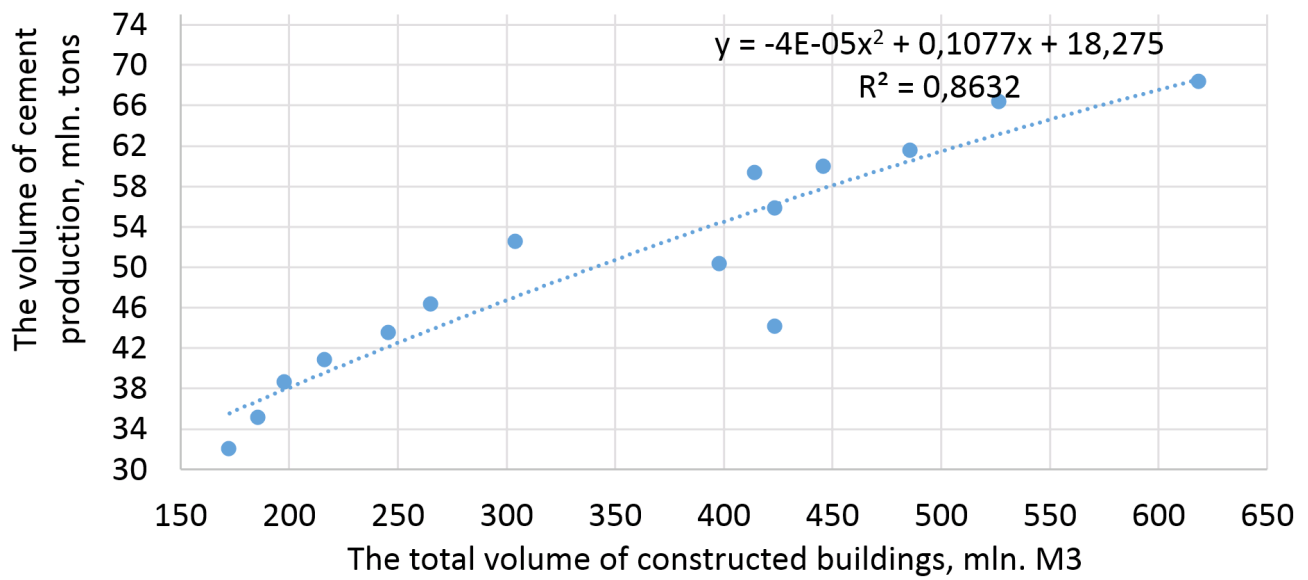

Figure 2. Relation between volume of constructed buildings and volume of cement production in Russia 
Table 2. Depreciation of cement factories fixed assets [Vysotsky 2014, Guz 2015]

\begin{tabular}{|c|c|c|c|c|}
\hline \multirow{2}{*}{$\begin{array}{c}\text { Total production } \\
\text { capacity, mln. tons }\end{array}$} & \multicolumn{3}{|c|}{ Distribution of fixed assets by functioning time, mln. tons } \\
\cline { 2 - 5 } & $>55$ years & $55-35$ & $35-25$ & $<25$ years \\
\hline 100.1 & 25.8 & 43.5 & 5.4 & 25.4 \\
\hline
\end{tabular}

erals, the extraction of which is considered to be relatively safe for the environment. However, the increase in production volumes and exploitation of new fields lead to increasing of disturbed areas and contaminated lands. In addition, due to high rate of transport costs in price of the building materials, the fields usually located near the areas with intensive construction, which are densely populated [Pivovarova 2015].

In this paper we attempt to summarize the information about the innovative technologies used in the processing chain of cement production and to determine the prospects of their implementation in Russia.

\section{MATERIALS DESCRIPTION}

\section{Mining}

Extraction of clay and limestone is carried out, as a rule, in quarry, which has a significant negative impact on the environment in the surrounding areas: pollution of air, soil, sediment, water, the formation of large depression cones, etc. Given the extremely lenient mechanism of emissions state regulation and imperfect tax system, the only significant obstacle to the development of deposits of non-metallic minerals is the process of withdrawal of land for industrial purposes.

The main impact of quarry is the destruction of natural objects within the quarry and on the territory of overburden dumps. Beyond the quarry, main environmental impact caused by dusting of overburden dumps, and pollutant emissions from blasting and the engines of road-construction equipment and vehicles. There is also a risk of pollution and changes in the chemical composition of groundwater [Tazhetdinova 2012].

\section{Limestone}

As a possible compromise could be the implementation of production technology without blasting and tightening ecological requirements for the equipment. In [Volkov et al. 2013, Kurchin et al. 2013] the proposed room-and-pillar mining method for limestone. The authors argue that it is possible without losses of production efficiency, especially in the northern regions with severe climatic conditions [Kozlov et al. 2015].

There are some examples of the limestone deposits underground mining in the world practice: in Korea [Yung et al. 2007], in some regions of the United States [Esterhuizen et al. 2008], and in European countries [Daniel and Careddu 2011]. In support of transition to underground mining, in addition to reduce dependence on climatic conditions, we would also like to point two essential arguments discussed by Parker [1996]:

1) stripping and restoration requirements are eliminated;

2) additional reserves are often available beneath the quarry floor, under pit slopes, or under adjoining property.

In [Bliss et al. 2008] it was also noted that underground limestone mining has some advantages, in comparison with the quarrying, especially if the field is located near populated areas, where there are special requirements for noise, vibration and emissions.

Returning to the question of blasting operations rejection, it should be noted that there is a successful practice of rock excavation by heavy rippers [Aggregates Business Europe 2007] or milling combines [Ermakov and Hosoev 2013]. These machines are used when limestone deposits are located in areas with high population density. This quarrying method is also preferable due to lower environmental impact (decrease the emissions into the atmosphere [Bratchikov et al. 2012]).

Another significant advantage of this method is increasing the production process flexibility. It is especially important when the selective quarrying is needed. Studies show [Safronov et al. 2015] that the most effective is the use of modern hydraulic excavators, although, it depends on the specifics of the field, of course.

\section{Clay}

Typically, clay is quarrying with the use of excavators. The process of clay extraction is almost completely automated. Significant fact is that clay refers to soft mineral resources. In low 
(negative) temperature conditions it solidifies, so the use of different techniques and methods of insulation is necessary.

One of the main problems of clay quarrying, in addition to general Russian quarry problems, is inefficient use of industrial areas after the exhaustion of the deposit resources. There are many examples of illegal dumps formation in such places [Nazarenko 2011]. Similar problems occur not only in Russia. For example, one of the main problems connected with clay harvesting in Ghana is the lack of post-production land reclamation, according to [Sarkodie et al. 2014].

Note that the problem of improving the clay extraction technologies is not enough discussed in scientific literature, despite the lack of a real alternative to quarrying, unlike most other nonmetallic minerals. In our opinion, it is connected with a minor role of the clay industry in national economies (excluding the effect in related industry branches).

\section{CEMENT PRODUCTION}

\section{Cement production technologies}

Raw materials for cement production are carbonate rocks (limestone, chalk, marl, marble), clay rocks (clay, loam, clay shale) and various additives (diatomite, tripoli).

Cement production consists of two main stages: clinker production and clinker grinding. Depending on the method of the raw materials compound preparation, there are dry, wet and combined methods of clinker production. In the first method, the initial mixture is obtained as a powder, in the second as a slurry. The third method is an "intermediate process chain", which may be based on one of two previous methods. The largest share in the Russian cement industry takes a wet method of production (Table 3 ).

If we compare their effectiveness, the most preferred is a dry method, the share of which in total cement production reaches in Japan 100\%,

Table 3. Types of furnaces in Russian cement industry [Kasyanov and Han 2009]

\begin{tabular}{|c|c|c|}
\hline Type & Share, $\%$ & \% of total capacity \\
\hline "Wet" & 85 & 83 \\
\hline "Dry" & 9 & 17 \\
\hline Shaft & 6 & 0 \\
\hline
\end{tabular}

in India - 93\% in Europe - 90\% (average), in the USA - 82\% [Potapov 2013]. In this regard, the strive of Russia to increase the share of dry cement production looks very reasonable.

Many Russian scientists consider "dry method" as a panacea for national cement industry. However, we would like to underline that there are also alternative aspects of the industry development. Moreover, dry cement production could be relatively ineffective, what we can see on the example of China industry [ $\mathrm{Lu} \mathrm{2009].} \mathrm{So,} \mathrm{the}$ implementation of such projects should be based not only on the desire to adapt successful foreign practice, but also on a careful study of the environmental and economic situation in the region [Teslya et al. 2015].

\section{Clinker substitutes}

Up to $80 \%$ of the cement production costs are the expenses for clinker. They partly include the cost of fuel ( $20 \%$ of total cement cost). At the same time, about $40 \%$ of the energy is consumed in the process of clinker grinding [Dvorkin and Dvorkin 2011]. It opens wide perspectives for the development and implementation of clinkerless cement manufacturing technologies [Brito and Saikia 2013], which reduce the emissions of harmful substances and the amount of used mineral raw resources [NCA 2016].

In the USSR part of waste in cement production reached 26\% (1980), i.e. from 137 million tonnes of raw materials, 36 million tons were the wastes of mining and processing industries (for example, blast furnace slag). Currently, this share dropped to $15-17 \%$ due to various reasons [Zarko et al. 2011].

\section{Energy efficiency of the cement factories}

Another direction of the cement industry development is increasing energy efficiency [Worrell et al. 2013]. [Imbabi et al. 2012] showed that economic efficiency of cement factories depends significantly on the availability of energy-saving technologies.

Besides the fact that the wet method is energy-intensive [CM Pro 2010], in Russian cement industry used such fuels as natural gas (88\%), coal $(11 \%)$ and shale $(1 \%)$ [Nikolaichuk and Diakonova 2016], whose prices are characterized by annual stable growth [Nikolaichuk and Tsvetkov 2016]. Energy consumption of Russian cement plants is shown in Table 4. 
Table 4. Energy intensity of cement production methods [BBT 2015]

\begin{tabular}{|c|c|c|c|c|}
\hline \multirow{2}{*}{ Method } & Year of launch & $\begin{array}{c}\text { Annual average fuel } \\
\text { consumption, } \\
\text { kg.OE./ton of clinker }\end{array}$ & $\begin{array}{c}\text { Annual average electricity } \\
\text { consumption, } \\
\mathrm{kw} \text {-hr/ ton of cement }\end{array}$ & $\begin{array}{c}\text { Average energy } \\
\text { consumption, } \\
\mathrm{kg} . \text { OE./ton of cement }\end{array}$ \\
\hline \multirow{2}{*}{ Dry } & before 1989 & 146.6 & 154.6 & 198.2 \\
\cline { 2 - 5 } & after 2008 & 106.4 & 122.5 & 147.4 \\
\hline Wet & after 2008 & 189.2 & 121.9 & 229.6 \\
\hline Combine & - & 147.2 & 99.6 & 180.6 \\
\hline
\end{tabular}

It should be noted that the transition to dry cement production method, the development of clinker substitutes and implementation of energy saving strategies are caused by a desire to reduce environmental impact [Imbabi et al. 2012, Habert et al. 2010], in addition to producing tangible economic effect. In this connection, the sustainable development of the Russian cement industry should be based on inter-industrial collaboration. Significant perspective in this matter has the development of small bioenergy enterprises, based on peat and wood processing [Cherepovitsyn and Tsvetkov 2016], which could be cooperated with cement factories.

\section{Advanced technologies in public documents}

In [BBT 2015] 16 "best available technologies" are marked whose implementation can increase the sustainability of the cement industry of Russia. The main ones are listed below (some of them have already been mentioned):

- development of clinker substitutes;

- development of dry cement production method based on modern scientific and technological base;

- using of waste as energy resource;

- cooperation between cement factories and heat generating companies to generate additional heat;

- development, implementation, maintenance of operational and continuous requirements of the energy and environmental management systems;

- using of modern filtration systems, and implementing measures to reduce dust emissions;

- reduction of gaseous emissions: $\mathrm{NO}_{\mathrm{x}}, \mathrm{SO}_{2}$, $\mathrm{CO}_{2}$, etc.;

- decreasing the noise from the production process;

- creating the decree and implementation of the regular monitoring and measurement of the emissions parameters.
This document is comprehensive and detailed, as evidenced by the presence of large list of particular measures, based on extensive statistical analysis. However, the implementation of all proposed measures in each new / modernized enterprise is questionable in the absence of free access of Russia to foreign technologies. However, we tend to agree that the sustainable development of the cement industry requires new regulation system, which should describe the process of Russian cement plants functioning in details.

Similar ideas, but in a more limited form set out in the source [IEA and WBCSD 2009], where advanced technologies are divided into four segments: thermal and electric efficiency, alternative fuel use, clinker substitution, carbon capture and storage.

\section{DEVELOPMENT OF INDUSTRY}

\section{Mining}

The analysis of cement industry promising technologies showed that, even with the mass implementation of clinker substitutes, the demand for limestone and clay in the coming years will slightly decrease. This is confirmed by the experience of the USSR, where only one third of the raw material was provided by the waste.

The development of limestone underground mining can be promising for widespread implementation. However, despite the potentially equal cost of production (in comparison with quarrying), the practice of mining shows a much higher capital expenditures, for example, for realization of room-and-pillar mining method. In Russian conditions, such projects could be implemented in the northern regions.

Promising and feasible in the current situation are non-blasting methods of limestone quarrying, taking into account the successful experience of their implementation, as well as the availability of the necessary technologies in Russia. 
Akey step for solving the problem of low efficiency of clay and limestone quarry is the improvement of legal documents in the field of environmental management. It is necessary to develop a development strategy for the industry, which will give an opportunity to implement the capital-intensive environmental projects (including measures for land reclamation) without loss of enterprises competitiveness in regional and international markets [Didenko et al. 2015].

\section{Cement production}

Russian cement industry, mainly operates using wet process. Despite the presence of a trend for the transition to more efficient technologies (production of dry and combined), the required investment, predicted in [Kasyanov 2009] are a significant deterrent to the development of the industry.

Improving the energy efficiency of cement factories is one of the key trends of the industry development. The possible way, offered in [BBT 2015], is the union of plants with energy companies. Moreover, Russia's scientific and technological base makes possible to reduce the cost of energy by realization of the local energy resources potential [Tcvetkov and Strizhenok 2016].

Given the capital and energy intensity of clinker production process, as well as significant amount of accumulated waste from processing facilities [Pushkin and Wiseman 2013], with high probability the possibility of clinkerless technologies development can be predicted.

\section{CONCLUSION}

The basis for the development of cement production technologies, as well as necessary resource for their functioning is capital - and knowledge-intensive process. In developed countries, this process is supported by the state regulation system in the field of environmental protection [Cherepovitsyn and Ilinova 2016]. These conditions have not been established in Russia yet. Moreover, in the current difficult economic situation, the possibility of state support for industry is very limited. In this regard, the introduction of such measures as mandatory environmental audit and certification according to ISO 14000 [Lashina and Petrov 2013] standards can lead to bankruptcy of most enterprises.
Despite the promising and proven by the international experience cost-effectiveness of innovative projects implementation in the cement industry, the implementation of all "best available technologies", proposed in [BBT 2015], is unrealizable to date.

As an intermediate solution could be vertical and cross-industry cooperation based on resource-saving technologies, which will subsequently liberate some financial resources for the modernization of the existing and the creation of new high-tech facilities.

\section{Acknowledgements}

This paper is based on research carried out with the financial support of the grant of the Russian Science Foundation "The purpose-oriented complex program of the Russian Arctic development" (project No. 14-38-00009). Peter the Great St. Petersburg Polytechnic University.

\section{REFERENCES}

1. Aggregates Business Europe 2007. Alternatives to drilling and blasting. URL: http://www.aggbusiness.com/categories/breaking-drilling-blasting/ features/alternatives-to-drilling-and-blasting/ (17.05.2016).

2. BBT - Bureau of best available technologies 2015 . Information-Technical Reference for the best available technologies. Cement Production. Federal Agency on Technical Regulating and Metrology, 2015. 305 p. URL: http://www.burondt.ru/NDT/ NDTDocsDetail.php?UrlId=494\&etkstructure $\mathrm{id}=1872$ (17.05.2016).

3. Bliss J.D., Hayes T.S., Orris G.J. 2008. Limestone - A Crucial and Versatile Industrial Mineral Commodity. USGS Fact Sheet 2008-3089. URL: https://pubs.usgs.gov/fs/2008/3089/fs2008-3089. pdf (17.05.2016).

4. Bratchikov N.V., Rubtsov I.V., Antipov D.A. 2012. The introduction of blast-free technology of extraction of hard rock in the Rostov region. Journal „Mining Industry” No. 2, p. 44 URL: http:// www.mining-media.ru/ru/article/ogr/2475-vnedrenie-bezvzryvnoj-tekhnologii-dobychi-krepkikhgornykh-porod-v-rostovskoj-oblasti (17.05.2016).

5. Cherepovitsyn A., Ilinova A. 2016. Ecological, Economic and Social Issues of Implementing Carbon Dioxide Sequestration Technologies in the Oil and Gas Industry in Russia. Journal of Ecological Engineering, 17(2), 19-23. DOI: 10.12911/22998993/62281. 
6. Cherepovitsyn A.E., Tsvetkov P.S. 2016. Methodical Approach to Evaluation of the Russian Peat Deposits Exploitation Attractiveness Based on Geology-Technological Criteria. International Journal of Applied Engineering Research, 11(7), 5072-5078.

7. ClimaTechWiki 2010. Energy Efficiency and Saving in the Cement Industry. Official website. URL: http://www.climatetechwiki.org/technology/energy-saving-cement (17.05.2016).

8. CM Pro 2010. Until 2017 the existing cement plants need to be upgraded or be forced to close. Official website. URL: http://cmpro.ru/rus/main/ issled/analitika/cemzavodclose.html (17.05.2016)

9. CM Pro 2016. SoyuzCement statistical data. URL: http://sdelanounas.ru/blogs/46357/ (17.05.2016).

10. Daniel P., Careddu N. 2011. Underground mining in perspective. Publicaciones Litos S.L., Spain URL: http://www.litosonline.com/en/articles/en/126/underground-mining-perspective (17.05.2016).

11. Didenko N., Kunze K., Skripnuk D. 2015. Russian Export Strategy and Social Sector: Consequences of Resource-Oriented Exports on Population of Russia. Mediterranean Journal of Social Sciences. 6(5). Suppl. 2, 473-481.

12. Didenko N., Skripnuk D. 2014. The impact of energy resources on social development in Russia. WIT Transactions on Ecology and the Environment, 190(1), 151-159.

13. Dvorkin L.I., Dvorkin O.L. 2011. Construction mineral binding materials. Infra Engineering. 544 p. URL: https://books.google.ru/books?id=EWuhBAA AQBAJ\&printsec $=$ copyright\&hl $=$ ru\&source $=$ gbs pub_info_r\#v=onepage\&q\&f=false (17.05.2016).

14. Ermakov S.A., Hosoev E.V. 2013. Technologyecological assessment of non-explosive development of overburden rocks and coals Elginskys field. International Journal of Applied and Basic Research No. 8. URL:http://cyberleninka.ru/ article/n/tehnologo-ekologicheskaya-otsenka-bezvzryvnoy-razrabotki-vskryshnyh-porod-i-ugleyelginskogo-mestorozhdeniya (17.05.2016).

15. Esterhuizen G.S., Dolinar D.R., Ellenberger J.L., Prosser L.J., Iannacchione A.T. 2008. Roof Stability Issues in Underground Limestone Mines in the United States. NIOSH-Pittsburgh Research Laboratory Pittsburgh, PA, USA. 8 p. URL: http://www. cdc.gov/niosh/mining/UserFiles/works/pdfs/rsiiu. pdf (17.05.2016).

16. FSS - Federal State Statistics Service of Russia (2016). Official website. URL: http://www.gks.ru (17.05.2016).

17. Guz V.A. 2015. Building materials industry. The main problems and prospects of development: The aging of fixed assets. Report during the working visit of Denis Manturov (the Minister of Industry and Trade) in the Krasnodar region. 13 p.
18. Habert G., Billard C., Rossi P., Chen C., Roussel N. 2010. Cement production technology improvement compared to factor 4 objectives. Cement and Concrete Research, 40, 820-826. DOI: 10.1016/j. cemconres.2009.09.031.

19. IEA and WBCSD 2009. Cement Technology Roadmap 2009. Carbon emissions reductions up to 2050. https://www.iea.org/publications/freepublications/publication/Cement.pdf (17.05.2016).

20. Imbabi M.S., Carrigan C., McKenna S. 2012. Trends and developments in green cement and concrete technology. International Journal of Sustainable Built Environment. 1(2), 194-216. DOI: 10.1016/j.ijsbe.2013.05.001.

21. Interfax information service (2016). Official website. URL: http://www.interfax.ru/business/433354 (17.05.2016).

22. Brito J., Saikia N. 2013. Recycled Aggregate in Concrete. Springer-Verlag London. 448 p. DOI: 10.1007/978-1-4471-4540-0.

23. Kasyanov P. Han D. 2009. Assessment of the Russian cement industry transition to the best available technologies. Interim Technical Report. European Communities, 2009. 42 p. URL: http://airgovernance.eu/pdf/Technical_Report_Evaluation_of_ costs_of the_Russian_cement_industrys_transition_to_BAT_RU.pdf $(17.05 .2016)$.

24. Kozlov A., Gutman S., Zaychenko I., Rytova E., Nijinskaya P. 2015. Environmental management on the basis of complex regional indicators concept: case of the Murmansk region. IOP Conference Series: Materials Science and Engineering 6. Ser. „6th International Scientific Practical Conference on Innovative Technologies and Economics in Engineering", 12-73.

25. Kurchin G.S., Volkov E.P., Zaytseva E.V., Kirsanov A.K. 2013. Environmental problems in the extraction of nonmetallic building materials in Russia. Modern problems of science and education. No. 6 . URL: http://www.science-education.ru/ru/article/ view?id=10500 (17.05.2016).

26. Lashina V.V., Petrov A.I. 2013. An analysis of the environmental aspects of cement production in the Russian Federation. Mining Informational and Analytical Bulletin, No. 3, 390-393. URL: http:// www.giab-online.ru/files/Data/2013/3/390-393 Lashina_-_4_str.pdf(17.05.2016).

27. Lu H., Masanet E., Price L. 2009. Evaluation of Life-Cycle Assessment Studies of Chinese Cement Production: Challenges and Opportunities. Proceedings of the 2009 ACEEE Summer Study on Energy Efficiency in Industry. 13 p. URL: https:// china.lbl.gov/sites/all/files/aceee-lca-cement-productionjuly-2009.pdf (17.05.2016).

28. Nazarenko N.V. 2011. Problems of land reclamation in the quarries of common minerals in the Bel- 
gorod region and ways of their solution. Problems of regional ecology. No. 2.

29. NCA - New Chemistry Analytics (2016). Official website. URL: http://newchemistry.ru/letter. php?n_id=1895 (17.05.2016).

30. Nikolaichuk L.A., Diakonova V.D. 2016. Current state and prospects of development of the market of gas motor fuel in Russia. Internet journal "Naukovedenie", 8(2). DOI: 10.15862/106EVN216 (17.05.2016).

31. Nikolaichuk L.A., Tsvetkov P.S. 2016. Prospects of Ecological Technologies Development in the Russian OilIndustry. International Journal of Applied Engineering Research, 11(7), 5271-5276.

32. Parker J. 1996. Everybody goes underground eventually. Aggregate Manager, 6, 30-35.

33. Pivovarova I. 2015. Systematic Approach in Ecological Zoning. Journal of Engineering \&Applied Sciences, 10(1), 11-15.

34. Potapov V., Yashina O., Borodenok D. 2013. Overview of the cement industry in the countries of the Customs Union. Ernst \& Young (CIS) B.V. 28 p. URL: http://www.ey.com/Publication/vwLUAssets/EY-Cement-industry-in-Customs-Unioncountries-Eng/\$FILE/EY-Cement-industry-inCustoms-Union-countries-Eng.pdf (17.05.2016).

35. Pushkin K.G., Wiseman Y.I. 2013. Methodological approaches to development and identification of the best available technologies on through the example use of ferrous slags. Vestnik MGSU. No. 10, 183-195. URL: vestnikmgsu.ru/index.php/ru/ archive/article/download/1002 (17.05.2016).

36. Safronov V.P., Zaitsev Y.V., Safronov V.V. 2015. Efficiency of use of the equipment for realization of technologies of production limestones and dolomites without explosion. News of the Tula State University. Technical Sciences, No. 7. URL: http://cyberleninka. $\mathrm{ru} /$ article/n/effektivnost-ispolzovaniya-oborudovaniya-dlya-realizatsii-bezvzryvnyh-tehnologiy-dobychiizvestnyakov-i-dolomitov (17.05.2016).

37. Sarkodie P.A., Kuffour C., Agyapong D. 2014. Environmental Impact of Clay Harvesting at Mpraeso Amanfrom in the Kwahu- West Municipal of the Eastern Region of Ghana. International journal of innovative research and development, 3(8), 4045. URL: http://www.academia.edu/10257976/ Environmental_Impacts_of_Clay_Harvesting (17.05.2016).

38. Tazhetdinova N.S. 2012. Geoecological assessment of the environmental impact of non-metallic building materials extraction in the Astrakhan region. $\mathrm{PhD}$ paper (dissertation). $145 \mathrm{p}$.
39. Tcvetkov P., Cherepovitsyn A. 2016. Prospects of CCS Projects Implementation in Russia: Environmental Protection and Economic Opportunities. Journal of Ecological Engineering, 17(2), 24-32. DOI: $10.12911 / 22998993 / 62282$.

40. Tcvetkov P., Strizhenok A., 2016. Ecological and economic efficiency of peat fast pyrolysis projects as an alternative source of raw energy resources. Journal of Ecological Engineering 17(1), 56-62. DOI: $10.12911 / 22998993 / 61190$.

41. Techart Research 2010. Review of the Russian cement market. URL: http:/www.techart.ru/files/publications/72.pdf (17.05.2016).

42. Teslya A., Cherepovitsyn A., Vyboldina E., Fedoseev S. and Kozmenko S. 2015. The Concept of Economic Growth of the Construction Industry in St. Petersburg. MATEC Web of Conferences, 53 () 01005 DOI: http://dx.doi.org/10.1051/matecconf/20165301005.

43. Volkov E.P., Kurchin G.S., Zaytseva E.V., Kirsanov A.K. 2013. Determination of the best configuration room-and-pillars for environmentally safe mining technology nonmetallic building materials. Modern problems of science and education. No. 5. URL: http://www.science-education.ru/ru/article/ view?id=10215 (17.05.2016).

44. Vysockiy E.V. 2013. Tendency and prospects of Russian cement market development. Construction Materials Journal, 66-69. URL: http://rifsm.ru/u/fl/ itm5722.pdf (17.05.2016)

45. Vysotsky E.V. 2014. Energy Efficiency Assessment of Russian cement plants. Industry Outlook. Report at the CemEnergy Conference, 6-8.

46. Worrell E., Kermeli K., Galitsky C. 2013. Energy Efficiency Improvement and Cost Saving Opportunities for Cement Making. An ENERGY STAR Guide for Energy and Plant Managers. Document Number 430-R-13-009. 142 p. URL: https://www. energystar.gov/sites/default/files/tools/ENERGY\%20STAR\%20Guide\%20for $\% 20$ the $\% 20$ Cement\%20Industry\%2027_08_2013_Rev\%20 js\%20reformat\%2011192014.pdf (17.05.2016)

47. Yung Y.B., Sunwoo C., Chung S.K. 2007. Design and reliability of pillar performance for underground limestone mine in Korea. In: Ribeiro e Sousa, Olalla and Grossmann (Eds). 11th Congress of the International Society for Rock Mechanics, Taylor \& Francis Group, London, 833-837.

48. Zarko V.I., Guz V.A., Kabanov A.A., Vysotsky E.V. 2011. Reserves base of secondary resources in the production of building materials. Journal "AlitInform" No. 2, 11-27. 